\title{
Utility of C-reactive protein in the early diagnosis of anastomotic leakage in colorectal surgery
}

\author{
Utilidad de la proteína C reactiva en el diagnóstico oportuno de fuga de anastomosis \\ cirugía colorrectal
}

\section{Guillermo R. Guevara-Morales ${ }^{1 *}$, Marco A. Regalado-Torres ${ }^{1}$, Eduardo Cantarell-Castillo', Ricardo Castro-Salas ${ }^{2}$, Rebeca Maldonado-Barrón ${ }^{3}$ and Juan C. Castellanos-Juárez ${ }^{3}$}

${ }^{1}$ Department of General Surgery; ${ }^{2}$ Surgical Oncology Department; ${ }^{3}$ Coloproctology Department, Hospital Regional de Veracruz, Instituto de Servicios y Seguridad Sociales de los Trabajadores del Estado, Veracruz, Veracruz, Mexico

\begin{abstract}
Introduction: The anastomotic leakage $(A L)$ in colorectal surgery is a complication feared by the increase in morbidity and mortality. The rate of AF is reported from 1 to $25 \%$. Making the diagnosis early is difficult. Objective: To determine the diagnostic performance of the $C$ reactive protein $(C R P)$ in a cohort of patients undergoing elective colorectal surgery with anastomosis. Method: A prospective, comparative study was conducted in 138 patients undergoing elective anastomosis with colorectal surgery, analyzing the serum values of CRP on postoperative days 1, 3, 5 and 7, as well as leukocytes and other abdominal sepsis data. Results: The AL rate was 6.5\%, the CRP values were significantly higher in the group of patients with AF on the 3rd postoperative day; with a cut-off point of $18.5 \mathrm{mg} / \mathrm{dl}$ on the third postoperative day, it obtained sensitivity $81 \%$, specificity $91 \%$, positive predictive value $45 \%$, negative predictive value $98 \%$. Conclusion: Measurement of CRP on the third postoperative day in patients undergoing elective colorectal surgery with primary or secondary anastomosis allows the identification of septic complications including leakage of anastomosis.
\end{abstract}

KEY WORDS: Anastomotic leakage. Colorectal surgery. C reactive protein.

\section{Resumen}

Introducción: La fuga de anastomosis (FA) en cirugía colorrectal es una complicación temida por el incremento de la morbímortalidad. La tasa de FA se reporta desde el 1 hasta el 25\%. Realizar el diagnóstico de forma temprana es difícil. Objetivo: Determinar el rendimiento diagnóstico de la proteína $C$ reactiva $(P C R)$ en una cohorte de pacientes sometidos a cirugía colorrectal electiva con anastomosis. Método: Se realizó un estudio prospectivo, comparativo, en 138 pacientes sometidos a cirugía čolorrectal con anastomosis de forma electiva, analizando los valores séricos de la PCR los días 1, 3, 5 y 7 del posoperatorio, así como los de leucocitos y otros datos de sepsis abdominal. Resultados: La tasa de FA fue del 6.5\%, y los valores de la BCR fueron significativamente más altos en el grupo de pacientes con FA en el tercer día del posoperatorio. Con un punto de corte de $18.5 \mathrm{mg} / \mathrm{dl}$ en el tercer día del posoperatorio se obtuvo una sensibilidad del $81 \%$, una especificidad del $91 \%$, un valor predictivo positivo del $45 \%$ y un valor predictivo negativo del $98 \%$. Conclusión: La medición de la PCR en el tercer día del posoperatorio en pacientes sometidos a cirugía colorrectal electiva con anastomosis primaria o secundaria permite identificar las complicaciones sépticas, incluida la FA.

PALABRAS CLAVE: Fuga de anastomosis. Cirugía colorrectal. Proteína $C$ reactiva.

\author{
Correspondence: \\ *Guillermo R. Guevara Morales \\ Av. Díaz Mirón esquina Sayula s/n \\ fraccionamiento moderno, \\ C.P. 91918, Veracruz, Veracruz, México \\ E-mail: grobertoguevara@gmail.com
}

Date of reception: 15-03-2018

Date of acceptance: 24-04-2018

DOI: 10.24875/CIRUE.M18000066
Cir Cir. 2018;86:38

Contents available at PubMed www.cirugiaycirujanos.com 


\section{Introduction}

Anastomotic leakage $(A L)$ in colorectal surgery is a dreaded complication due to the increase in morbidity and mortality of patients in whom it occurs. In an attempt to avoid or decrease AL, multiple predisposing factors have been described, such as old age, use of corticosteroids, hypoalbuminemia, anemia, inflammatory bowel disease and distance from the anastomotic line to the anal margin, among others. Despite the identification of risk factors, the emergence of intestinal stapling and improvement of surgical techniques, the reported $A L$ rate ranges from 1 to $25 \%{ }^{1}$. AL diagnostic time is variable and ranges between 3 and 45 days postoperatively; the goal is to diagnose it early in order to reduce the severity of the complication and mortality, which sometimes can be as high as $39 \%$.

$A L$ is defined as the escape of luminal content through the surgical junction of two hollow viscera, which can be established with contrasted imaging studies, computed tomography or by presence of perianastomotic leak or abscess observed in a laparotomy, which may or may not (subclinical AL) show data consistent with systemic inflammatory response ${ }^{2-4}$.

Establishing the AL diagnosis in colorectal surgery in a timely manner is difficult and involves a challenge for surgeons, even when there is close post-surgical monitoring. Abdominal, respiratory and neurological signs and symptoms generally occur after the fourth postoperative day. In addition, sensitivity and specificity of some imaging tests (ultrasound, computed tomography, contrasted enema) can sometimes underestimate the $\mathrm{AL}$ diagnosis due to their false-negative rates ${ }^{5-9}$.

In some clinical studies, the usefulness of some serum inflammatory response markers, such as C-reactive protein (CRP), which has a half-life of 19 hours, to early establish the AL diagnosis has been demonstrated ${ }^{10-12}$.

The purpose of this study was to determine the diagnostic performance of CRP in a cohort of patients undergoing elective colorectal surgery with anastomosis.

\section{Method}

A prospective, descriptive, comparative study was carried out in patients undergoing elective colorectal surgery with resection and anastomosis (primary and secondary), between July 2014 and November 2017.
CRP serum values of were recorded at first, third, fifth and seventh postoperative day, as well as white blood cell determination, vital signs and some other data related to abdominal sepsis. All were recorded over the first 7 days in a database. The patients $\overline{\text { had }}$ a followed-up visit at 30 days. The rest of the studied variables were age, gender, surgery indication, type of anastomosis, resection location and hospital length of stay.

Patients with suspicion or evidence of pre-surgical infection, patients with inflammatory bowel diseâse, patients with protective stoma and those with incomplete clinical records were excluded.

Within the postoperative management, the patients started the oral route 3-5 days after the surgical event. For pain control, a non-steroidal anti-inflammafory drug (NSAID) plus an opioid were used. AL was corroborated by clinical and laboratory data, plus simple and contrasted abdominal and pelvic computed tomography (Fig. 1); in some cases, laparotomy was performed.

The AL treatment was carried out according to findings on imaging studies, patient clinical status and surgeon's criteria (laparotomy, percutaneous drainage or conservative management).

\section{Statistical analysis}

Descriptive statistics were used, with percentages and means being calculated. The chi-square testand Mann-Whitney test were used according to the type of variables. A receiver-operator characteristic (ROC) curve was plotted in order to determine the area under the curve on postoperative days 1, 3 and 5 , as well as the positive predictive value, the negative predictive value and the likelihood ratios. The analysis- was carried out with the SPSS 20 program (SPSS Pinc., Chicago, IL, USA). A p-value $<0.05$ was considered statistically significant.

This work was carried out with previous authorization of the local ethics and research committee.

\section{Results}

During the study period, 138 patients were analyzed, out of which 52 were men (37.6\%) and 86 women $(62.3 \%)$, with an average age of $56 . \overline{9} \pm$ 13.4 years. The indication for surgery was cancer (clinical stages I, IIA, IIB, IIC, IIIA of the TNM classification, $7^{\text {th }}$ ed. $)^{13}$ in 30 cases $(21 \%)$, diverticular disease in $65(47 \%)$ and other indication in $43(31 \%)$. As 


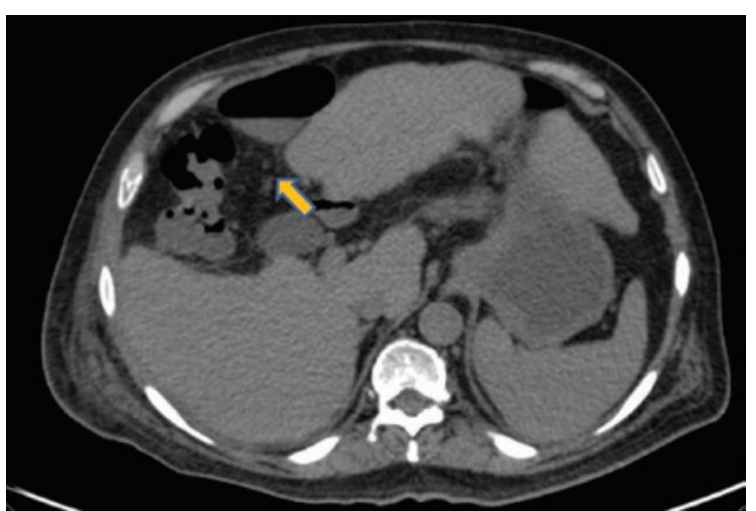

Figure 1. Abdominal tomography axial section showing data consistent with perianastomotic abscess (fluid and gas) in a patient with ileotransverse anastomosis leakage.

for comorbidities, $14 \%$ of the patients had type 2 diabetes mellitus and $11.4 \%$ had hypertension.

The resection site was the right colon in 36 patients $(26 \%)$, left colon in $79(57.24 \%)$ and the rectum in $23(16.6 \%)$. In $94.92 \%$ of cases, the resection was performed by laparotomy, and in $5 \%$, laparoscopic surgery was carried out. In $85 \%$ of patients, pneumatic testing was performed to confirm anastomosis integrity, and in $100 \%$, permeability and absence of leaks were verified. The type of anastomosis performed was mechanical in 75 patients (54\%) and manual in $63(45.65 \%)$. Hospital length of stay was $7.7 \pm 12$ days (Table 1).

The $A L$ rate was $6.5 \%$ in patients who underwent to colorectal surgery. According to the AL diagnosis, the patients were divided in two groups: group $A$, 129 patients without $A L$, and group $B$, nine patients with AL. The diagnosis was made between days 3 and 5 postoperatively; only in one patient was it established after 20 postoperative days. Among the studied characteristics, there was only significant difference in the days of hospital stay (7.3 days vs. 24.5 days; $p=0.0014)$. White blood cell values and the signs and symptoms of $A L$ showed no differences before postoperative day 5 .

When the CRP values were analyzed according to the presence of $A L$ (Table 2), no statistical significance was found at first postoperative day $(p=0.22)$; on days 3,5 and 7, CRP values were significantly higher in group $B$ (third day, $p<0.001$, and fifth day, $\mathrm{p}=0.001$ ) (Fig. 2).

The ROC analysis included the CRP values, and the area under the curve was 0.45 at first postoperative day, 0.98 at third postoperative day and 0.96 on the fifth day; since early diagnosis was a goal, the seventh day values were not included. The best
Table 1. Characteristics of patients undergoing colorectal surgery with anastomosis

\begin{tabular}{|c|c|c|}
\hline & $\mathbf{n}$ & $\%$ \\
\hline Age $56.9 \pm 13.4$ years & & $\stackrel{\frac{L}{\sigma}}{E}$ \\
\hline \multicolumn{2}{|l|}{ Gender } & $\overline{0}$ \\
\hline Males & 52 & 38 \\
\hline Females & 86 & 62 \\
\hline \multicolumn{2}{|l|}{ Indication } & ப் \\
\hline Cancer & 30 & $\xi 1$ \\
\hline Diverticular disease & 65 & -47 \\
\hline Other & 43 & 를 \\
\hline \multicolumn{2}{|l|}{ Comorbidity } & $\stackrel{(1)}{=}$ \\
\hline Type 2 diabetes mellitus & 19 & +74 \\
\hline Hypertension & 15 & '十1 \\
\hline \multicolumn{2}{|l|}{ Type of resection } & 으 \\
\hline Right colon & 36 & 26 \\
\hline Left colon & 79 & 57 \\
\hline Rectum & 23 & 16 \\
\hline \multicolumn{2}{|l|}{ Type of anastomosis } & $\bar{c}$ \\
\hline Manual & 63 & 45 \\
\hline Mechanical & 75 & $=54$ \\
\hline \multicolumn{2}{|c|}{ Hospital length of stay $7.7 \pm 12$ days } & $\frac{1}{2}$ \\
\hline
\end{tabular}

Table 2. C-reactive protein values $(\mathrm{mg} / \mathrm{dL})$ at postoperative days according to the study group

\begin{tabular}{lcc|c}
\hline Postoperative day & Group A & Group B & 1. \\
\hline Day 1 & 11.1 & 11.6 & $<0.7$ \\
Day 3 & 9.8 & 30.22 \\
Day 5 & 8.1 & 21.3 & $<001$ \\
Day 7 & 7.4 & 11.6 & 0.005 \\
\hline
\end{tabular}

diagnostic performance over the measured days was that of third day, since with a cutoff point of $18.5 \mathrm{mg} /$ $\mathrm{dL}$, a sensitivity of $81 \%$, specificity of $91 \%$, a positive predictive value of $45 \%$ and a negative predictive value of $98 \%$ were obtained, with likelihood ratios of +9 and -0.02 (Fig. 3).

When the CRP values at third postoperative glay were assessed, it was $8.98 \mathrm{mg} / \mathrm{dL}$ (95\% confidence interval [CI]: 8.72-9.26) for patients without complications, whereas in subjects with $\mathrm{AL}$ it was $30.7 \mathrm{mg} / \mathrm{dL}$ (95\% Cl: 23.54-37.9), and in patients with some other complication (AL was ruled out), it was $14.18 \mathrm{mg} / \mathrm{dL}$ (95\% Cl: 12.6-20.6) (Table 3 and Fig. 4).

The rate of septic complications (including AL) was 14\%. According to Clavien-Dindo classification, in 2 patients (1.4\%) it was grade I, in $5(3.6 \%)$ it was grade II, in $4(2.8 \%)$ it was grade IIla, in $2(1.4 \%)$ it was grade IIIb, in $3(2.1 \%)$ it was grade IV, in $2(1.4 \%)$ it was grade IVb and only in $1(0.7 \%)$ it was grade V. 


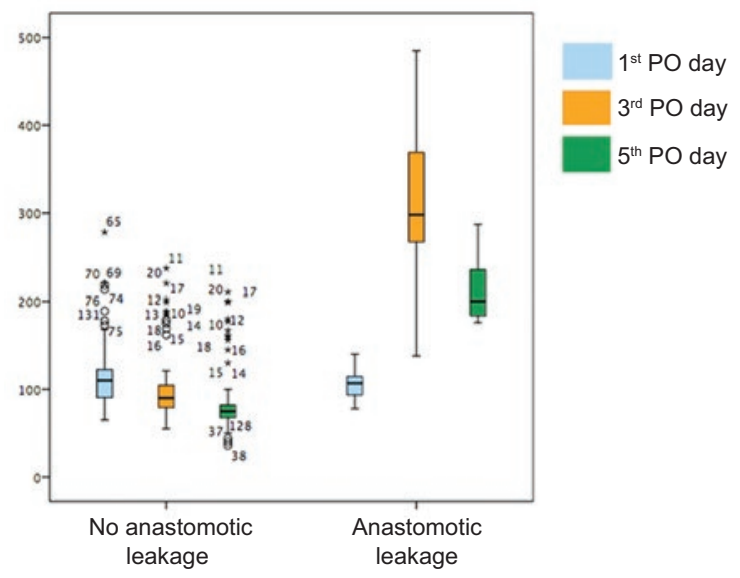

Figure 2. Box-and-whisker plot showing $C$-reactive protein values ( $\mathrm{mg} / \mathrm{dL}$ ) on postoperative days 1,3 and 5 according to the study group.

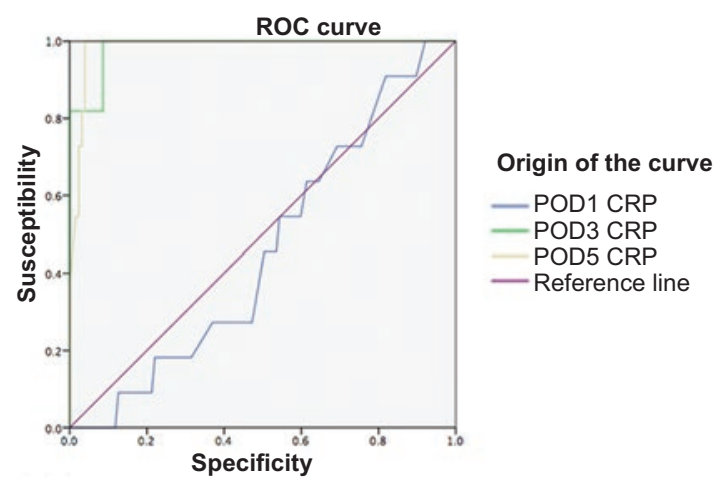

Figure 3. C-reactive protein values ROC curve analysis on postoperative days 1, 3 and 5. Area under the curve at first day, 0.45; third day, 0.98 ; and fifth day, 0.96 .

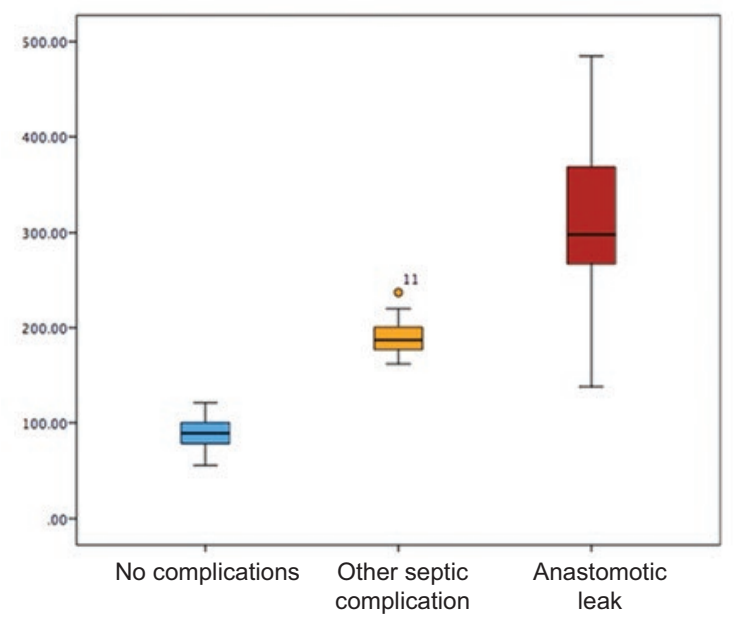

Figure 4. Box-and-whisker plot showing $C$-reactive protein values $(\mathrm{mg} / \mathrm{dl})$ at postoperative day 3 according to the type of complication.

\section{Discussion}

Establishing AL early diagnosis is difficult. Sensitivity and specificity of $\mathrm{AL}$ diagnosis by surgeons are
Table 3. C-reactive protein values $(\mathrm{mg} / \mathrm{dL})$ at postoperative day 3 according to the type of complication

\begin{tabular}{|c|c|c|}
\hline & CRP values & $95 \% \mathrm{Cl}$ \\
\hline Without complication & 8.98 & $8.72-\frac{2}{2} .26$ \\
\hline Anastomosis leak & 30.7 & 23. $54 \div$ \\
\hline Other septic complication & 14.18 & 17.620 .6 \\
\hline
\end{tabular}

estimated to be $41 \%$ and $59 \%$, respectively ${ }^{14}$. This can be explained by the appearance of data consistent with inflammatory response after postoperative day $5-6^{5-9}$.

Numerous strategies have been described to identify the risk of $\mathrm{AL}$, such as assessing anastomotic perfusion or using indocyanine green, which has been shown to lower the AL rate by up to $5 \%{ }^{15}$.

Some markers have been assessed as AL predictors, such as peritoneal fluid cytokines, CRP, procalcitonin, calprotectin and fatty acid binding proteins (I-FABP), among others, and have been associated with good diagnostic accuracy $y^{3,16,17}$.

CRP is a marker with broad availability and nowelevated or lower cost than the above-mentioned ones. Its usefulness as an AL predictor in colorectal surgery has been assessed in multiple studies. In this work, it was shown to possess high sensitivity and specifieity; however, the cutoff point obtained was higher than in some published studies, such as the meta-analysis conducted by Warschkow et al. ${ }^{18}$ with six studies ( $n=1,832)$, where, with a cutoff point $>13.5 \mathrm{mg} / \mathrm{d}$ fon the fourth postoperative day, a sensitivity of $68 \%$ and specificity of $83 \%$ were obtained $(95 \% \mathrm{Cl}$ : $77-90 \%)$, with a negative predictive value of $89 \%$.

Perhaps our results resemble more those published by Singh et al. ${ }^{11}$, in whose meta-analysis, which included seven studies ( $n=2,483$ ), the AL rate was $9.6 \%$ with a cutoff point of $17.2 \mathrm{mg} / \mathrm{dL}$, an area underthe curve of 0.81 and a negative predictive value of $97 \%$.

CRP has been documented not differ from procalcitonin for establishing AL diagnostic performance on postoperative day 3 . Moreover, its sensitivity and specificity increase when combined with the use of other biomarkers, as it was concluded in the study conducted by Reisinger et al. ${ }^{3}$, where CRP showed a sensitivity of $100 \%$ and specificity of $64 \%$, with an area under the ROC curve of 0.82 for a value $>9.9 \mathrm{mg} /$ $\mathrm{dL}$ on postoperative day 4; furthermore, with the addition of calprotectin, specificity increases to $89 \%$, with an area under the curve of $0.93^{10}$.

By itself, a CRP value $>14 \mathrm{mg} / \mathrm{dL}$ at third postoperative day is indicative of septic complication, which 
should be investigated with a diagnostic algorithm (blood count, electrolytes, chest X-ray, urine and wound cultures, and even contrasted computed tomography) in order to rule out or confirm $A L^{12}$.

Another point to consider are AL-predicting scores or scales. A scoring with the diagnostic protocol proposed by Den Dulk et al. ${ }^{1}$ (which includes the use of CRP), tested in 1,066 patients, showed a reduction in $\mathrm{AL}$ diagnosis time ranging from 1.5 to 4 days.

In general, the limitation of this type of studies when assessing $A L$ is the lack of a true reference method ${ }^{3}$, and in this study in particular the main limitation was the lack of CRP measurements at patient admission or daily measurements, the lack of a control group and not having imaging studies in all patients. It should be mentioned that the hospital where the present study was conducted is public and has resident doctors on training, which may have contributed to these results.

\section{Conclusion}

CRP measurement at third day after surgery in patients undergoing elective colorectal surgery with primary or secondary anastomosis allows identifying septic complications, including AL, which should be confirmed by contrasted imaging studies or laparotomy, or both, depending on patient clinical status and surgeon's criteria.

\section{Acknowledgements}

To the group of general surgeons, surgical oncologists and colorectal surgeons from Hospital Regional ISSSTE Veracruz for enabling the performance of this work.

\section{Conflicts of interests}

The authors declare that they have no conflicts of interest.

\section{References}

1. Den Dulk M, Noter SL, Hendriks ER, Brouwers MA, vañ der Vlies $\mathrm{CH}$, Oostenbroek RJ, et al. Improved diagnosis and treatment of anastomotic leakage after colorectal surgery. Eur J Surg Oncol. 2009;35:420-6.

2. Peel AL, Taylor EW, Surgical Infection Study Group. Proposed definitions for the audit of postoperative infection: a discussion paper. Ann R Coll Surg Engl. 1991;73:385-8.

3. Reisinger KW, Poeze M, Hulsewé KW, van Acker BA, van Biinen AA Hoofwijk AG, et al. Accurate prediction of anastomotic leakage after colorectal surgery using plasma markers for intestinal damage and inflamation. J Am Coll Surg. 2014;219:744-51.

4. Martin G, Dupré A, Mulliez A, Prunel F, Slim K, Pezet D. Validation of a score for the early diagnosis of anastomotic leakage following elective colorectal surgery. J Visc Surg. 2015;152:5-10.

5. Bellows CF, Webber LS, Albo D, Awad S, Berger DH. Early predictors of anastomotic leaks after colectomy. Tech Coloproctol. 2009;13:41.

6. Kingham TP, Pachter HL. Colonic anastomosis leak: risk factors, diagnosis, and treatment. J Am Coll Surg. 2009;208:269.

7. Bokey EL, Chapuis PH, Fung C. Postoperative morbidity and mortality following resection of the colon and rectum for cancer. Dis Colon Reetum. 1995:38:480.

8. Alves A, Panis Y, Pocard M, Regimbeau JM, Valleur P. Management of anastomotic leakage after nondiverted large bowel resection. J A $\bar{m}$ Coll Surg. 1999;189:554.

9. Ortega-Deballon P, Radais F, Facy O, D'Athis P, Masson D, Charles PE, et al. C-reactive protein is an early predictor of septic complications after elective colorectal surgery. World J Surg. 2010;34:808.

10. Cousin F, Ortega-Deballon P, Bourredjem A, Doussot A, Giaccaglia V, Fournel I. Diagnostic accuracy of procalcitonin and C-reactive protein for the early diagnosis of intra-abdominal infection after elective colorectal surgery: a meta-analysis. Ann Surg. 2016;264:252-6

11. Singh PP, Zeng IS, Srinivasa S, Lemanu DP, Connolly AB, Hi $A$ AG. Systematic review and meta-analysis of use of serum C-reactive-protein levels to predict anastomotic leak after colorectal surgery. $\mathrm{Br} J$ Surg. 2014:101:339-46.

12. Almeida AB, Faria G, Moreira H, Pinto-de-Sousa J, Correla-da-Silva $\mathrm{P}$, Maia JC. Elevated serum $\mathrm{C}$-reactive protein as a predictivetactor for anastomotic leakage in colorectal surgery. Int J Surg. 2012;87-91

13. AJCC. Colon and rectum cancer staging. AJCC Cancer Staging Manual. $7^{\text {th }}$ ed. New York: Springer; 2010.

14. Karliczek A, Harlaar NJ, Zeebregts CJ, Wiggers T, Baas PC, van $=D a m$ GM. Surgeons lack predictive accuracy for anastomotic leakage ingastrointestinal surgery. Int J Colorectal Dis. 2009;24:569-76.

15. Blanco-Colino R, Espin-Basany E. Intraoperative use of ICG fluorescence imaging to reduce the risk of anastomotic leakage in colorectal surgery: a systematic review and meta-analysis. E Tech Coloproctol. 2018;22:15.

16. Matthiessen $P$, Henriksson $M$, Hallböök $O$, Grunditz $E$, Norén B,Arbman G. Increase of serum C-reactive protein is an early indicator of subsequent symptomatic anastomotic leakage after anterior resection. Colorectal Dis. 2008;10:75

17. Burak U, Murat G, Yexsim E. Early prediction of anastomotic leakage after colorectal surgery by measuring peritoneal cytokines: prospective study. Int J Surg. 2008:6:28-35.

18. Warschkow R, Beutner U, Steffen T, Müller SA, Schmied BM, Gütter U, et al. Safe and early discharge after colorectal surgery due to O-reactive protein: a diagnostic meta-analysis of 1832 patients. Ann Surg. 2012;256:245-50 